\title{
Beliefs and Practices About Remote Teaching Processes During the Pandemic: A Study with Chilean Mathematics Teachers
}

\author{
Farzaneh Saadati ${ }^{{ }^{*}}$, Valentina Giaconi ${ }^{2}$, Eugenio Chandia ${ }^{3}$, Nicole Fuenzalida ${ }^{1}$, \\ Mariana Rodríguez Donoso ${ }^{1}$ \\ ${ }^{1}$ Center for Advanced Research in Education (CIAE), Universidad de Chile, CHILE \\ ${ }^{2}$ Instituto de Ciencias de la Educación, Universidad de O'Higgins, CHILE \\ 3 Universidad de Concepción, CHILE
}

Received 11 May 2021 - Accepted 10 August 2021

\begin{abstract}
This study determines the factors associated with teachers' beliefs and practices during the pandemic. An online instrument designed and implemented for Chilean mathematics teachers, with a total of 423 math teachers participating. The instrument is found psychometrically valid to study teachers' pedagogical-technological beliefs and their remote practices. The results show teachers' high self-efficacy levels regarding the personal use of technology, but moderate selfefficacy in integrating technology in teaching. Moreover, teachers see a much more active role for themselves than for students in online activities. Gender differences were only significant for teaching practices, where the results reported women as more active than men. Teacher age is not recognized as a factor affecting teachers' pedagogical-technological beliefs and their remote practices. Finally, the study confirms a significant influence of socioeconomic context in teachers' beliefs and practices during the pandemic. It recommends that policymakers need to provide adequate resources and knowledge to support teachers in integrating technologies in distance education, especially those working in the public sector.
\end{abstract}

Keywords: beliefs, mathematics teachers, pandemic, remote emergency education, teacher practices

\section{INTRODUCTION}

The pandemic has prompted changes in emergency educational systems (UNESCO, 2020). According to Azevedo et al. (2020), in more than 180 countries schools have closed and replaced face-to-face classes with diverse online activities. This situation mandates educational communities to implement emergency remote teaching, which implies a new experience and huge challenges for teachers. Teachers are facing an unprecedented emergency of remote teaching all around the world. Experts believe that such changes are here to stay (UNESCO, 2020) and that teachers will require a tremendous amount of training and adaptation. Azevedo et al. (2020) indicate that the general difficulties for all teachers in this area are related to the development of distance classes, the lack of access to appropriate technology, and lack of skills to utilize information and communications technology (ICT) for themselves as well as for their students. Besides these challenges, in mathematics education researchers emphasized on some specific challenges of technology integration in the teaching (Almanthari et al., 2020; Kersaint, 2007; Wachira \& Keengwe, 2011). Castro and colleagues (2020) indicate that these challenges and changes fomented by the pandemic make way for new research areas. In particular, they highlight the necessity to understand the beliefs and practices of teachers associated with the integration of technology in their teaching, which corresponds to this article's focus.

There is a traditional debate among researchers and educators about the relation between teachers' beliefs and practices (Guskey, 2002; Thompson, 1992). Several researchers have noted the importance of Mathematics

(c) 2021 by the authors; licensee Modestum. This article is an open access article distributed under the terms and conditions of the Creative Commons Attribution License (http://creativecommons.org/licenses/by/4.0/). 


\section{Contribution to the literature}

- This study brings additional contributions in the field of teachers' beliefs and practices in remote education.

- It also gets a deeper understanding of a Mathematics teacher' pedagogical-technological beliefs and practice during the COVID 19 pandemic.

- The study clearly shows the role of socioeconomic status on teachers' pedagogical-technological beliefs and practices.

teachers' instructional beliefs and self-efficacy when studying their instructional practices (e.g., Saadati et al., 2019; Stipek et al., 2001). A literature review done by Mumtaz (2000) highlighted the role of teachers' beliefs about teaching and learning with ICT or their pedagogical-technological beliefs as a central factor affecting the level of ICT integration in their teaching practices. So far, all these studies consider normal education activities when studying the system of teachers' beliefs and practices. Such systems should not be considered in isolation without the context since there are other factors that fundamentally impact teachers' beliefs and practices. In a normal situation, teachers have a level of freedom to integrate or not integrate technology in their teaching, however, in the pandemic it was the only option for teachers. Not only for teaching purposes, teacher have to replace technology for other activities, which went through face to face communicating before the pandemic. This emergency transition from face-to-face to distance environment has created an unpleasant situation for teachers in their beliefs about integrating technology into education, especially for those inexperienced teachers. Thus, this situation affects teachers' beliefs about online learning. As Juggernath and Govender (2020) have argued that even in a technology-rich context, teacher beliefs play a major role in teachers' use of technology in education. The emergency remote education is a novel phenomenon, spanning many months and its characteristics will likely continue to be present for much longer. It is therefore essential to study teachers' beliefs and practices in this particular context of remote education and also to determine the factors that influence this system.

Mumtaz (2000) addressed three interlocking aspects for studying the successful implementation of ICT in teaching: teacher, school, and policymakers. Castro and colleagues (2020) also declared the financial resources as a fundamental aspect influencing the emergency remote education. So far, we know that in developing countries, economic segregation has greater impact on educational segregation (OECD, 2020). With emergency online education, inequality worsens between rich and poor students (Azevedo et al., 2020). The Word Bank (2020) presented a scenario predicting that learning poverty could increase by 10 percentage points in Low-and Middle-income countries. In Chile, a strong indicator for categorizing students based on their socioeconomic level is the type of school that they enter. There are three different types of schools in the country, which are municipal (administrated by each City municipality with public financing), subsidized (privately administered, but financed through public resources), and private (administered and financed privately). Those municipal and subsidized schools are usually serving students from the lowest quintiles of the socioeconomic level. As research shows a high number of members of these particular educational community would not be able to adequately access or use high-tech educational services (Bravo \& Castillo, 2020). In addition, teachers' personal and professional characteristics such as age, gender, and year of expertise can potentially influence the beliefs and practices associated with technology.

The subject of online teaching and learning has been widely debated, however, when we get to online emergency education, it is a prolific issue, which demands more research. Without a doubt, the education system and legislators need to review the challenges of teachers and the current actions in order to get prepare for the future and control the effect of the pandemic on the quality of education. With this at the forefront, our study presents the mathematics teachers' technologicalpedagogical beliefs and practices during the pandemic. In particular, we focus on pedagogical-technological belief barriers that Chilean mathematics teachers face due to the transition in remote education, age, gender and socioeconomic inequality of their students that affect the quality of their instruction during the pandemic. Specifically, this research addresses the following research questions:

1. What are teachers' pedagogical-technological beliefs and practices during the emergency remote education and how are they correlated?

2. What are the differences between teachers' pedagogical-technological beliefs and their practices across different types of schools?

3. What are the differences between teachers' pedagogical-technological beliefs and their practices across individual teacher characteristics? 


\section{Teachers' Beliefs and Practices}

Teachers' beliefs as an unspoken set of unconsciously held assumptions can offer us insight as to how teachers act in relation to issues of education such as learning, curriculum, schooling, and the transfer of knowledge (Levin \& Wadmany, 2006). Considering beliefs and practices as a system is imperative to understanding the teaching process. There are different theoretical models that try to explain this system. Some models argue for a bidirectional relationship as an alternative model, suggested by Guskey (2002) who explains that the significant changes in teachers' beliefs tends to occur after the changes in their classroom practices occur, for example, after they have tried a new teaching approach or a change in their teaching procedures or classroom format. Prawat (1992) suggested that teachers' beliefs function as a filter for their practices and decisions in the classroom, and therefore promote or hinder change on their instruction. Among the different relationship models that can be established, one of them - a unidirectional relationship model between beliefs and practices - explains that teachers' beliefs affect their own teaching practices (Stipek et al., 2001; Thompson, 1992). However, there are other factors and internal conditions of teachers and students that impact these relationship models.

Usually, teachers claim to have high rates of selfefficacy with technology use (Arpaci \& Basol, 2019; Santi et al., 2020), however, this claim does not correspond to the levels of their self-efficacy to integrate technology in the teaching and learning processes (Gillis \& Krull, 2020; Marshall et al., 2020). This difference, in fact, can be explained by the contextual conditions and limitations, especially those factors that influence teachers' practices due to the pandemic. These factors directly related to the teachers' conditions: (a) the lack of adequate equipment (Santi et al., 2020); (b) lack of and quality of internet (Santi et al., 2020); (c) absence of primary and continued training to manage school classrooms (Marshall et al., 2020); and (d) low frequency of interaction and communication with students due to sustained drop in their participation in synchronous and asynchronous classes (Marshall et al., 2020). Additionally, there are some other factors that are related to students' limitations but they can indirectly affect teachers' practices. For example, students' external and familyrelated factors affect their particular class participation and hence, their learning levels, which influence their teacher's practice. Among the main barriers of students, we should mention domestic distractions, increased anxiety, demotivation, access to the technology especially for low-income students, and the expense of the time and attention they must devote to their learning (Alemany-Arrebola et al., 2020; Gillis \& Krull, 2020).

All these unique conditions caused by the pandemic and the involuntary transformation in education has initiated in the education system and teacher practice.
Therefore, we believe a rigorous study is required to understand teachers' belief and practices system.

\section{Pedagogical-Technological Beliefs related to Remote Teaching}

In this article, we concentrate on two main categories of beliefs, as pedagogical-technological beliefs, which can influence teachers' remote teaching process; beliefs about self and beliefs about ICT. The first category, beliefs about self, refers to self-efficacy beliefs or beliefs that teachers have about their skills at carrying out tasks (Bandura, 1997). We are using two dimensions in this category, (1) self-efficacy in the use of technology, (2) self-efficacy in integrating technology in teaching. Selfefficacy in integrating technology in personal tasks (STP) indicates beliefs about capability to be successful with a technology related task (Huffman et al., 2013; McDonald \& Siegall, 2001). This dimension of self-efficacy measures teacher's beliefs on their own abilities to successfully apply technology in their personal lives. We also consider self-efficacy in integrating technology in teaching tasks (STT) as the teachers' belief in their ability to teach via technology to positively affect student learning. According to De Ponte et al. (2002), it is a crucial factor in predicting how teachers can effectively utilize technologies in their teaching, especially in science and mathematics.

Teachers' beliefs about ICT is another category of beliefs that is demonstrate by several theories as a factor that impact teachers' practices and that they will also be modified through experiences based on it (Karatas, 2014; Slough \& Chamblee, 2000). They argue that the vision teachers maintain about technology and how friendly their relation with it is, are crucial factors in determining the effective use of technologies and instruction, especially in the teaching of mathematics and sciences (De Ponte et al., 2002). However, based on different studies, teachers' views on technology and online learning can be dichotomized. Teo (2009) suggested that teachers that are surrounded by effective support structures that provide them with successful experiences in technology would develop more positive judgments regarding their ability to use technology in teaching. The teachers' point of view on technology can also represent a significant barrier to the use of technology in the classroom (Levin \& Wadmany, 2006). Karatas (2014) also recognizes the negative beliefs and attitudes of teachers towards the use of technology as internal barriers to developing technology-based practices. Therefore, both negative and positive beliefs about technology integration in teaching are important. In the second category, teachers' beliefs about ICT have been developed in two dimensions. These two dimensions are (1) beliefs about the potential of technology integration in teaching (BPT), and (2) beliefs about the barriers that arise through technology integration in teaching (BBT). We consider BPT that refers to believing in the potential 
of online teaching to promote learning. On the other hand, the Barriers dimension BBT corresponds to the perceptions and experiences of the teachers about their difficulties in implementing online teaching. For the majority of teachers, online teaching is a new practice for which they have never prepared (Bakar et al., 2020; Marshall et al., 2020). Therefore, those teachers who are trying to implement online teaching experience some difficulties, especially in organizing their classroom activities (Almanthari et al., 2020).

\section{Teachers' Practice during the Remote Teaching}

Basically, mathematics and STEM teachers are more challenged than the rest of the teachers in establishing teaching strategies in this transition to remote teaching, especially to have effective pedagogical strategies for developing students' higher order cognitive skills (Keebler \& Huffman, 2020). There are several schools of thought to conceptualize effective online teaching practices. A range of practices presented by researchers are, in fact, encompass different teaching styles supported by different learning theories. For example, teachers' practices in which a teacher takes a mediator role are more associated with constructivist styles than those practices in which the teacher takes a prominent role (Ally, 2008). With a social constructivist perspective, what happens in the classroom should be studies in two different ways, by studying what teachers do and what students do. This pattern has been highlighted in a model presented in a study with Chilean mathematics teachers and their problem-solving practices (Saadati et al., 2019). These two components of practices for mathematics teachers are not presenting a dichotomized set of practices, rather a key to understanding the efficiency of the practices. In fact, it is about the role of a teacher to involve their students in their practices especially in the online teaching process. A study done by Kreber and Cranton (2000) highlights the need of teachers' higher-order cognitive skills to guide the collaborative efforts of their students to move from 'content reflection' to 'critical reflection' in online learning activities.

During the pandemic, the only option for teachers is the use of ICT affordances to develop online practices, though teachers might present difficulties trying to encourage their students to participate in learning activities. Carrillo and Flores (2020), upon reviewing 134 empirical studies about online teaching and learning practices in teacher education, concluded that online learning is the result of the interaction of three presence factors: social, cognitive and teaching presence. In the components presented for each of these three factors, we see that the effective online activities are subject to actions of a social and pedagogical nature and beyond the activities adopted only based the teacher. Gillis and Krull (2020) also suggested several strategies to improve the effectiveness of online teaching like maintaining clear and effective communication with their students, establishing structures of opportunities for students to connect with their peers, and offer flexibility in attending the classes and deadlines of homework. With this perspective, we consider two dimensions of practices associated with remote teaching processes: practices that focus on the teacher's contribution (PR_T) and those that focus on the student's contribution (PR_S).

In terms of instructional strategies, teachers emphasize that technology, readiness, including technological capabilities, whether using online (learning by television, radio, online applications), or offline (printed teaching materials, modules, textbooks) are necessary for supporting the success of online learning. However, several studies highlight the impact of teachers' initial or continuous training to utilizing technology in efficient ways (e.g., Marshall et al., 2020; Sepúlveda-Escobar \& Morrison 2020). Marshall et al. (2020) indicate that a majority $(92.4 \%)$ of teachers surveyed indicate that they had never taught online before the emergency transition and very few had received significant training from their school or district, which Sepúlveda-Escobar and Morrison (2020) also observe in Chile. Even with inexperience and lack of formal training, almost half (49\%) of teachers reported feeling at least somewhat prepared to deliver remote instruction. However, and despite the mandatory use of technology in the current scenario, before the pandemic, it was observed that the level of self-efficacy of teachers to integrate technologies in the teaching process was quite low, even when they felt comfortable with the technologies (Corry \& Stella, 2018). Arpaci and Basol (2019) also declare that teachers with high rates of selfregulation and self-efficacy have greater east of perceived use of technologies and a positive impact on the adoption of teaching strategies and practices that integrate technologies. In spite of this, high levels of anxiety caused by pandemic conditions negatively can affect levels of teacher self-efficacy and therefore the ease of use and perceived usefulness of such technologies.

The foregoing foments the teachers' belief that the new paradigm should focus on how students understand a lesson, rather than cover the established school curriculum (Rasmitadila et al., 2020). This is strengthened given the levels of digital literacy and resilience of current students, without observing differences between students from urban and rural schools, or by gender (Tran et al., 2020). Teachers have always been critical of the lack of student contribution in the online learning process. For example, Marshall et al. (2020) state that over half of the surveyed teachers $(57.2 \%)$ indicated that at least a quarter of their students did not have access to broadband internet outside of their school. Moreover, many students with access to the Internet, had to compete with other siblings to use their Internet-enabled devices for school work. As in Chile, Sepúlveda-Escobar and Morrison (2020) found that 
teachers from public schools claim that they have little or no interaction with their students when taking classes synchronously, which contrasts dramatically with students of private schools.

\section{METHODOLOGY}

The study is designed to evaluate Chilean mathematics teachers' perceptions and remote practices during the pandemic. To do so, a survey is designed and applied in an online manner to mathematics teachers. In this section, the profile of participants, the instrument, and finally the process of data analysis is all presented.

\section{The Instrument}

The instrument designed (Appendix) by the authors for this research consists of three parts: the first part requests demographic and personal information from the teachers with respect to gender, age, educational institution and platforms and technological equipment used. The second part is designed to capture Mathematics teachers' pedagogical-technological beliefs. The items in this construct are written based on prior theory of Bandura (1997) self-efficacy theory and an empirical study done by Karatas (2014). In this part, each item was measured with a five-point Likert scale ( 1 = totally disagree, 2 = disagree, 3 = neutral, $4=$ agree, and 5 = totally agree). This includes four different variables or dimensions:

1. STP (4 items): refers to teachers' beliefs on their ability to use general technology and social networks. An example of one of these items is: "I can use technology to communicate with friends and family."

2. STT (5 items): defined as the teachers' belief in their ability to teach through technology to positively affect student learning. One example of this is: "I can plan and successfully carry out activities online with my students."

3. BPT (8 items): the beliefs considered here refer to the possibilities that offer online teaching to promote learning. An example item is: "Teaching online allows me to give personalized feedback to each student."

4. BBT (8 items): perception of difficulties and barriers to online teaching. An example of an item is: "I find it difficult to adapt my face-to-face classes to my online practices."

The third part is designed to capture teachers' practices during the online teaching. It includes two different dimensions related to their actions during teaching. One of these variables refers to the teacher's contribution and the second to that of the student. The related items are adapted based on a previous study with Chilean mathematics teachers (Saadati et al., 2019). A 5-point Likert scale measures each item: 1 = Never, 2
= At least once a week, 3 = Several times per week, $4=$ All or almost every day, and $5=$ Every day and several times a day).

1. PR_T (10 items): teaching practices during the teaching-learning process related to the opportunities that teachers offer their students to participate in different learning experiences. An example of an item is "I propose activities so that my students can discuss and share their opinion"

2. PR_S (9 items): teaching practices that promote different opportunities of online learning based on student actions. One example of an item is "my students ask questions during my classes and/or online activities."

\section{Sample and Data Collection}

A survey designed by a team of two researchers and two expert teachers in order to provide the data for this study. A pilot study happened by inviting 10 mathematics teachers through email. They have been asked to respond to the questionnaire and write their comments and suggestions in order to improve the clarity of the items. After a revision based on the comments received from the pilot stage, the data collection process of the survey started in May 2020 and was completed at the end of July 2020. The survey data is held in "Google Forms" - a tool that allows diffusion in a virtual context. Two main methods were used to collect data, using email and social media. First, the coordinators of the study called the facilitators of several professional development programs and their training centers and asked them to share the link of the survey with their participants who are mathematic teachers. Second, the survey was disseminated online through social media of local groups of mathematics teachers and shared on the related groups in Instagram and Facebook. As a result, an adequate number of participations in the survey was provided.

A total of 423 in-service mathematics teachers participated in the survey study during May to July 2020. They were volunteer participants from various schools in Chile as municipal, subsidized, and private schools, with the only requirement that they should be mathematics teachers who are teaching at least one mathematics course in the time of participation in this study. Of the total sample, $73.8 \%$ correspond to women and $25.8 \%$ to men. The gender distribution of the participants is, in fact, similar to the gender distribution for math teachers reported by the Ministry of Education, in Chile $25.5 \%$ of math teachers are male (Ministry of Education Republic of Chile [MINEDUC], 2021). The average age was $\mathrm{M}=36.8$ (S.D. = 8.8). We found that $22.5 \%$ of teachers worked in municipal schools, $48.7 \%$ in subsidized schools and $17 \%$ in private schools. The rest of the teachers work in more than one type of school or institution. In addition, it is reported that teachers use 
Table 1. Standardized loadings in the final model (model 2)

\begin{tabular}{lcccccccc}
\hline Item & Loading $(\beta)^{* *}$ & S.E. & Item & Loading $(\beta)^{* *}$ & S.E. & Item & Loading $(\beta)^{* *}$ & S.E. \\
\hline STP 1 & 0.896 & & BPT 8 & 0.699 & 0.156 & PR_T 7 & 0.854 & 0.202 \\
STP 2 & 0.886 & 0.028 & BBT 1 & 0.697 & & PR_T 8 & 0.863 & 0.215 \\
STP 3 & 0.740 & 0.047 & BBT 2 & 0.534 & 0.089 & PR_T 9 & 0.416 & 0.195 \\
STP 5 & 0.931 & 0.038 & BBT 3 & 0.432 & 0.086 & PR_T 10 & 0.656 & 0.192 \\
STT 1 & 0.794 & & BBT 5 & 0.353 & 0.098 & PR_S 1 & 0.786 & 0.857 \\
STT 2 & 0.869 & 0.055 & BBT 6 & 0.725 & 0.112 & PR_S 2 & 0.061 \\
STT 3 & 0.893 & 0.052 & BBT 7 & 0.595 & 0.099 & PR_S 3 & 0.863 & 0.063 \\
STT 4 & 0.872 & 0.054 & PR_T 1 & 0.479 & & PR_S 4 & 0.607 & 0.071 \\
STT 5 & 0.670 & 0.063 & PR_T 2 & 0.707 & 0.183 & PR_S 5 & 0.429 & 0.078 \\
BPT 4 & 0.502 & & PR_T 3 & 0.768 & 0.194 & PR_S 6 & 0.879 & 0.053 \\
BPT 5 & 0.619 & 0.144 & PR_T 4 & 0.788 & 0.198 & PR_S 7 & 0.877 & 0.060 \\
BPT 6 & 0.649 & 0.143 & PR_T 5 & 0.842 & 0.216 & PR_S 8 & 0.436 & 0.068 \\
BPT 7 & 0.603 & 0.142 & PR_T 6 & 0.839 & 0.206 & PR_S 9 & 0.572 & 0.071 \\
\hline
\end{tabular}

${ }^{* *}$ All the loadings are significant at the $p<0.001$ level

various electronic devices for their teaching activities. Most have reported using laptops and smartphones; $98 \%$ of the participants use laptops and $96 \%$ use smartphones.

\section{Data Analysis}

The data analysis is made up of two stages. The first seeks to generate evidence of validity based on the internal structure and evaluates the reliability of each of the scales. To obtain validity evidence based on the internal structure (Rios \& Wells, 2014), confirmatory factor analyses were conducted to test the latent structure of the instrument (Shultz et al., 2013). The second stage uses the classical statistical methods of describing variables. Box plots and descriptive statistics describe the distribution of the variables and perceptions and practices. To study teachers' beliefs and practices and their relationship with categorical variables (gender and type of establishments where teachers work), ANOVA and t-student tests were used. For the ANOVA tests that indicated that there were statistically significant differences between the means, a post hock analysis with Tukey's correction was carried out to determine between which pairs of groups the differences were found. Finally, to study the relationship between variables of perceptions and practices, a correlation analysis was conducted, which facilitates determining whether there are positive, negative or null linear relationships between pairs of numerical variables. All statistical analyses were performed with the R software. For the psychometric analyses, the Lavaan (Rosseel, 2012) and Psych (Revelle, 2020) packages were used.

\section{RESULTS}

\section{Instrument Validity and Reliability}

The first model, model 1, had 6 correlated factors, each corresponding to a theoretical dimension. This model's fit was not satisfactory: (Chi-Square $=2878, d f=$ 974, CFI $=0.849$, RMSEA $=0.068$, SMRM $=0.083$ ), the problems with this model were the inverse items and the need to add correlations between the item errors of the dimension. The inverse items that did not work because they had very low factor loadings belong to the BPT (items 1, 2 and 3) and BBT (item 8) dimensions. In addition, two items that loaded in the STP dimension were eliminated because conceptually they did not correspond to this scale (items 4 and 6). Based on this, model 1 was modified by eliminating the inverse items and adding correlations between the errors of some pairs of items. Only pairs where both items belong to the same factor were correlated. The improved model, model 2, was properly fitted to the data (Chi-Square $=1326, d f=$ 677, $\mathrm{CFI}=0.937, \mathrm{RMSEA}=0.048, \mathrm{SMRM}=0.059$. In addition, all the items had high loads in their respective factors (Table 1), and small correlational residuals were observed (Kline, 2016). This model provides the evidence in favor of the theoretically proposed structure.

After identifying the factorial structure and eliminating the inverse items, the reliability of each dimension was estimated from Cronbach's alpha coefficient, and only the items that were maintained in the factorial model were considered. For the dimensions STP (4 items), STT (5 items), BPT (5 items), BBT (6 items), PR_T (10 items), and PR_S (9 items), the Cronbach's alpha coefficient was $0.93,0.91,0.75,0.75,0.91,0.91$, respectively. It is suggested that adequate reliability is at least 0.7 in research contexts (Shultz et al., 2013). Considering such results, we conclude that the dimensions of the instrument are sufficiently reliable.

\section{Teachers' Pedagogical-Technological Beliefs and Practices and Their Correlation}

As for teaching beliefs and practices, Figure 1 shows box-and-whisker plots that describe the distribution of teachers' responses in each dimension. In Table 2, we can see the means and standard deviations. We see that the $\mathrm{STP}$ takes very high values $(\mathrm{M}=4.28, \mathrm{SD}=1.05)$, providing evidence of positive beliefs among mathematics teachers regarding their own abilities to use technology. The STT dimension takes values larger than $3(\mathrm{M}=3.48, \mathrm{SD}=1.06)$ associated with teachers' agreement with items, but 


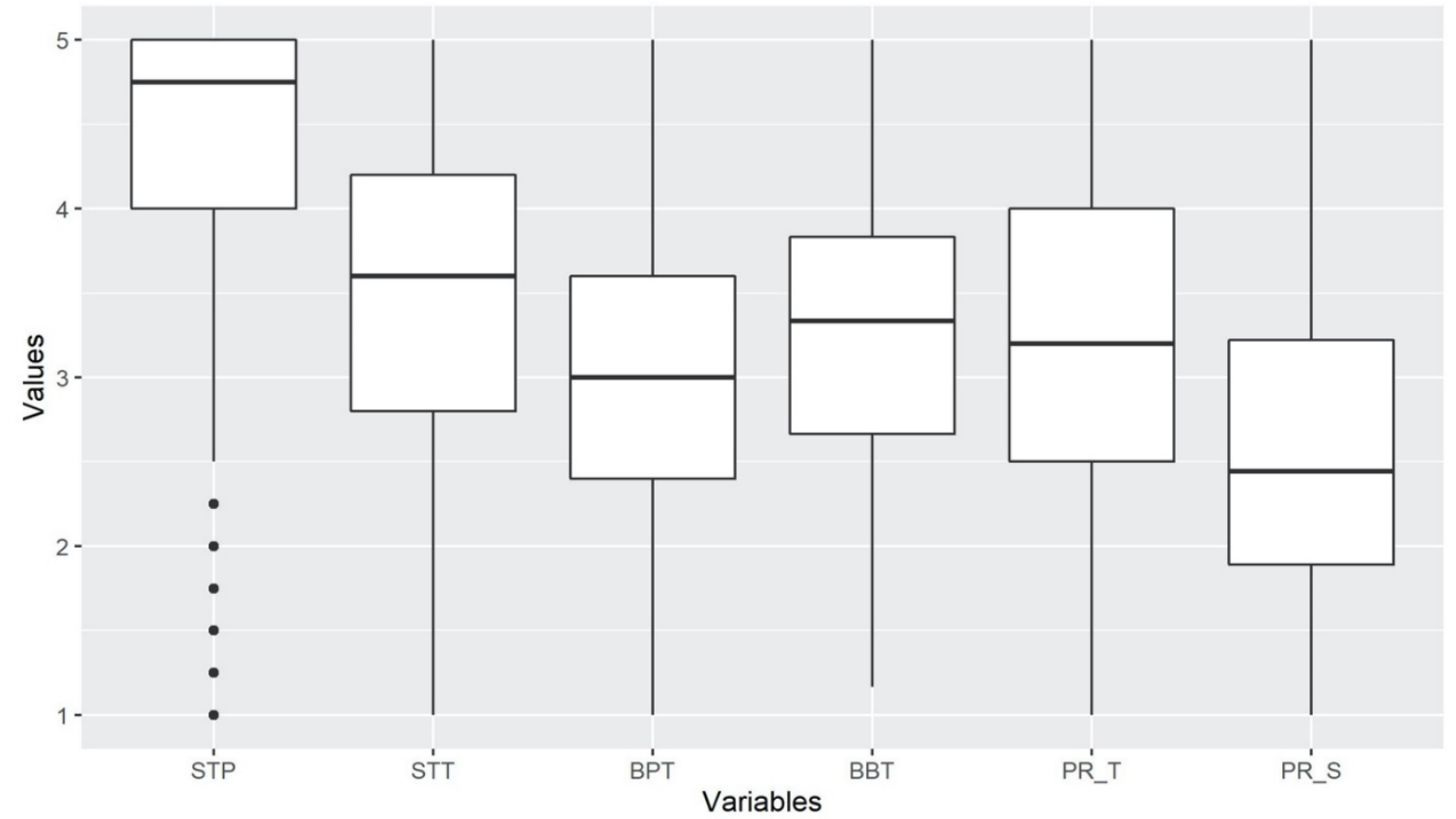

Figure 1. Box-and-whiskers diagrams of the survey questions

Table 2. Descriptive statistics and correlations $(r)$ between the variables. ${ }^{*} p<0.05,{ }^{* *} p<0.001$

\begin{tabular}{|c|c|c|c|c|c|c|c|c|}
\hline & Mean & SD & STP & STT & BPT & BBT & PR_T & PR_S \\
\hline$\overline{\text { STP }}$ & 4.28 & 1.05 & 1.00 & & & & & \\
\hline STT & 3.48 & 1.06 & $.62^{* *}$ & 1.00 & & & & \\
\hline BPT & 2.97 & 0.85 & $.20^{* *}$ & $.44^{* *}$ & 1.00 & & & \\
\hline BBT & 3.25 & 0.82 & .03 & $-.19^{*}$ & $-.21^{* *}$ & 1.00 & & \\
\hline PR_T & 3.20 & 0.91 & $.09^{*}$ & $.22^{* *}$ & $.13^{*}$ & $-.18^{*}$ & 1.00 & \\
\hline PR_S & 2.60 & 0.84 & .06 & $.30 * *$ & $.25^{* *}$ & $-.18^{*}$ & $.66^{\star *}$ & 1.00 \\
\hline
\end{tabular}

lower than what they have responded for the other selfefficacy scale. This difference indicates less confidence of teachers in their abilities to teach online. The graph shows that more than $25 \%$ of the teachers is in the interval less than 3, associated with a disagreement regarding their abilities for developing teaching tasks with technology.

In the BPT dimension, the distribution of the responses is observed around the neutral point $(M=2.97$, $\mathrm{SD}=0.85$ ), with approximately $50 \%$ of teachers with a tendency to agree and 50\% to disagree with the items in this dimension. Moreover, the mean value of the BBT is higher than $3(\mathrm{M}=3.25, \mathrm{SD}=0.82)$. As we mentioned before, the items of the BBT dimension were statements regarding problems and limitations associated with teacher' experience of online teaching. We observed a fair amount of agreement regarding the presence of these barriers, with a majority of the responses above the value 3 or neutral.

The dimensions PR_T and PR_S are measured with frequency scales. The PR_T dimension, has most of the values above the value 3 , corresponding to "Several times a week", indicating that there is a majority of teachers who are very active in their teaching practices $(\mathrm{M}=3.20, \mathrm{SD}=0.91)$. However, it has also been observed that at least $25 \%$ of the teachers are much less active, taking values between 1 and $2.5(\mathrm{M}=2.60, \mathrm{SD}=0.84)$. The distribution of the responses in PR_S dimension shows that teachers perceive that their students are not very active and participatory in relation to teaching activities, since the distribution of this variable takes much lower values than the previous one.

Table 2 also presents correlations between the variables, where we see that STP is significantly correlated with STT, which is to be expected, given its common nature. STP is also significantly related to BPT and PR_T. In contrast, STT has much large correlations in absolute values with variables associated with teaching. It means, teachers with greater self-efficacy in teaching show greater agreement with the potential of online teaching, greater disagreement with the barriers of online teaching and more active teaching practices from the perspective of the teacher and student. The correlation table also demonstrates that BPT has a significant negative correlation with barriers (BBT) and with teaching practices from the student's contribution. This indicates that the teachers who perceive that their students participate more, identify positive potentialities of online teaching. Negative correlations are observed between the BBT and the two variables of teaching practices (PR-T, PR_S), where teachers who perceive more difficulties have fewer active classes and perceive 
Table 3. Averages of the variables of beliefs and practices for each type of establishment

\begin{tabular}{|c|c|c|c|c|c|c|}
\hline & \multicolumn{3}{|c|}{ Mean (SD) } & \multirow{2}{*}{$F(2,370)$} & \multirow[b]{2}{*}{$p$} & \multirow{2}{*}{$\begin{array}{l}\text { Differences between } \\
\text { pairs }\end{array}$} \\
\hline & Municipal (MU) & Subsidized (SU) & Private (PR) & & & \\
\hline$\overline{\text { STP }}$ & $4.04(1.26)$ & $4.32(1.02)$ & $4.62(0.55)$ & 6.99 & $<.05$ & MU-PR, SU-PR \\
\hline STT & $3.23(1.20)$ & $3.44(1.00)$ & $3.87(0.88)$ & 8.11 & $<.001$ & MU-PR, SU-PR \\
\hline $\mathrm{BPT}$ & $2.88(0.87)$ & $2.91(0.83)$ & $3.16(0.76)$ & 2.96 & .053 & None \\
\hline BBT & $3.26(0.95)$ & $3.32(0.77)$ & $3.04(0.73)$ & 2.28 & .105 & None \\
\hline PR_T & $3.04(0.91)$ & $3.14(0.91)$ & $3.62(0.81)$ & 10.04 & $<.001$ & MU-PR, SU-PR \\
\hline PR_S & $2.33(0.83)$ & $2.52(0.77)$ & $3.13(0.84)$ & 22.22 & $<.001$ & MU-PR, SU-PR \\
\hline
\end{tabular}

Table 4. Averages of the variables of beliefs and practices for each gender

\begin{tabular}{lcccc}
\hline & \multicolumn{2}{c}{ Mean $(S D)$} & $T$ & $p$ \\
\cline { 2 - 3 } & Feminine $(\mathrm{N}=312)$ & Masculine $(\mathrm{N}=109)$ & $t(180.6)=.23$ & .855 \\
STP & $4.30(1.02)$ & $4.27(1.08)$ & $t(184.6)=-.40$ & .691 \\
STT & $3.48(1.05)$ & $3.52(1.07)$ & $t(196.0)=-1.86$ & .065 \\
BPT & $2.93(.86)$ & $3.10(.82)$ & $t(166.0)=-.24$ & .810 \\
BBT & $3.24(0.84)$ & $3.27(.75)$ & $t(196.0)=2.55$ & $.011^{*}$ \\
PR_T & $3.27(0.91)$ & $3.02(.87)$ & $t(188.1)=0.07$ & .943 \\
PR_S & $2.61(0.84)$ & $2.60(.84)$ &
\end{tabular}

${ }^{*} P$-value $<0.05$

that their students participate less. Finally, there is a very high correlation between PR_T and PR_S, showing that teachers who are more active perceive their students as more participatory as well.

\section{Teachers' Pedagogical-Technological Beliefs and Practices across Different Types of Schools}

ANOVA tests were conducted to determine whether there were significant differences in the mean scores on the variables of teachers' pedagogical-technological beliefs and practices across their types of schools; municipal, subsidized private, and private schools. The results show that there were statistically significant differences at the $p$-value $<0.01$ level in the STP scores, $F(2,370)=6.99$, the STT scores, $F(2,370)=8.11$, the PR_T scores, $F(2,370)=10.04$, and the PR_S scores, $F(2$, $370)=22.22$, for the three different types of schools. However, there were not any statistically significant differences in the BPT and BBT across these schools.

Table 3 shows that in all the variables, except BBT, the highest means are for teachers from private schools and the lowest for those from municipal schools. Furthermore, the differences are significant for all variables, except barriers. In addition, comparisons of means between pairs were made via a post-hoc analysis using the Tukey test. In most variables the significant differences are present between teachers of municipal and subsidized schools with those of private schools.

\section{Teachers' Pedagogical-Technological Beliefs and Practices across Teacher Characteristics}

The relationship between beliefs and practices with gender and age was also explored. The independentsamples $t$-tests were conducted to compare the variables scores for male and female teachers. Table 4 shows that there are no significant differences in the scores for males and females, except in the PR_T scores. The PR_T mean score for female $(M=3.27, S D=0.91)$ was significantly bigger that the mean score for male $(M=3.02, S D=.87)$. This difference indicates that the female teachers report more frequently of using different forms of activities in their practices during the pandemic that promote the participation and involvement of their students.

After considering the type of the schools, the one-way between-groups analysis of variance was conducted to explore the impact of age on teachers' pedagogicaltechnological beliefs and practices during the pandemic. Subjects were divided into four groups according to their age (Group 1: less than 30 yrs.; Group 2: 30 to 39yrs.; Group 3: 40 to 49 yrs.; Group 4: 50 yrs. and above). The actual differences in mean scores of all variables between the groups were quite small. Despite this fact, no significant and statistical differences were found in the variables of the study related to beliefs and practices for the four age groups (Table 5).

\section{DISCUSSION}

This study sets out to increase the understanding of the beliefs and practices of mathematics teachers during the first months of the pandemic that has brought about a global transformation in education. For this, the first stage of the study consisted of developing an instrument for online use to measure the variables of interest. The measurement scale was configured with 44 items associated with 6 sub-scales (STP, STT, BPT, BBT, PR_T, PR_S) as the study's theoretical recognized dimensions and also based on previous studies regarding mathematics teacher beliefs and practices (Giaconi et al., 2018; Saadati et al., 2019). These 6 sub-scales of the instrument demonstrated good psychometric properties with the sample of in-service mathematics teachers. The participants were required to teach at least one classroom online during the pandemic in Chile. The 
Table 5. Averages of the variables of beliefs and practices for each age interval

\begin{tabular}{lcccccc}
\hline & \multicolumn{3}{c}{ Mean (SD) } & \multirow{2}{*}{$F(3,372)$} & \multirow{2}{*}{$p$} \\
\cline { 2 - 5 } & Age $<30(\mathrm{~N}=56)$ & $30 \leq$ Age $<40(\mathrm{~N}=205)$ & $40 \leq$ Age $<50(\mathrm{~N}=69)$ & $50 \leq$ Age $(\mathrm{N}=46)$ & & 0.943 \\
STP & $4.46(0.96)$ & $4.27(1.08)$ & $4.25(1.02)$ & $4.12(1.09)$ & 0.420 \\
STT & $3.38(1.04)$ & $3.50(1.02)$ & $3.68(1.09)$ & $3.32(1.17)$ & 1.357 & 0.256 \\
BPT & $2.78(0.80)$ & $2.96(0.83)$ & $3.11(0.87)$ & $2.94(0.92)$ & 1.537 & 0.205 \\
BBT & $3.15(0.75)$ & $3.29(0.81)$ & $3.20(0.84)$ & $3.29(0.86)$ & 0.407 & 0.748 \\
PR_T & $3.34(0.91)$ & $3.22(0.88)$ & $3.03(0.94)$ & $3.25(0.97)$ & 1.290 & 0.278 \\
PR_S & $2.68(0.90)$ & $2.57(0.75)$ & $2.51(0.92)$ & $2.86(0.95)$ & 1.980 & 0.116 \\
\hline
\end{tabular}

instrument allows us to adequately measure the dimensions of this research, since evidence of validity was found in relation to its internal structure and adequate reliability.

When focusing on the relation between variables, logical correlations were detected. Teachers' beliefs about the barriers that arise by technology integration in teaching showed negative, but significant correlations with the other variables unless teachers' self-efficacy in personal use of technology. This pattern is logically accepted because this specific variable, in fact, refers to the difficulties that teachers have in the use of technology. These results display a relationship and coherence with international studies carried out during 2020 (Gillis \& Krull, 2020; Marshall et al., 2020; Rasmitadila et al., 2020; Sepulveda-Escobar \& Morrison, 2020) where teachers perceived evidence of complexities of pedagogical-technological beliefs that directly affect their instructional practices executed in the online classroom mode during the pandemic. There was also a high correlation between two types of teachers' selfefficacy as STP and STT. Though a high percentage of teachers claim that they feel more efficient when using technologies for a personal occasion rather than for their pedagogical abilities. The correlation between STP and STT is high and significant, however, more than $25 \%$ of the sample does not feel capable of using technologies in online teaching processes. This finding is consistent with other research, given the difference established between the perception of self-efficacy between using technologies outside and within an online teaching and learning setting (Gillis \& Krull, 2020; Marshall et al., 2020). In international research, this difference is explained by the lack of initial and continuous training in online teaching and learning models for teachers and their lack of experience with it (Corry \& Stella, 2018). In Chile, in particular, we should consider that approximately half of the teachers and their students do not have access to proper technology that could be used for education during the pandemic (Alemany-Arrebola et al., 2020; Gillis \& Krull, 2020), possibly because of inappropriate orientation of school and government leaders in providing the necessary context for online education before the pandemic.

Studies declare some internal factors interfere with teachers' self-efficacy in integrating technology in teaching tasks; for example, the knowledge that teachers acquired during their initial and/or continuous training (e.g., Horvitz et al., 2015). Unfortunately, the majority of teachers with little or no training in using technology and online learning had to decide quickly how to adjust their courses to remote teaching (Gillis \& Krull, 2020; Marshall et al., 2020). Additionally, the levels of anxiety and stress generated by the uncertain conditions of the pandemic in teachers can impact teachers' levels of selfefficacy and feasibility of use and integration of technologies in remote teaching processes. The foregoing confirms the significant relationships between cognitive and technological factors, and the continuous intention to use or adopt alternative or uncommon strategies for the online class modality (Arpaci \& Basol, 2019).

The results also show a high correlation between two aspects of online practices (PR_T and PR_S). From teachers' points of view, students' contributions in online class activities is less than what they do there. This difference in participation can be interpreted from the levels of digitization of the students and the distance of this level with that of their own teachers, leading them to question the teaching strategies implemented, or to not participate because of experiencing barriers to their learning or lack of motivation due to the pandemic (Gillis \& Krull, 2020; Tran et al., 2020). In fact, there are two factors influencing the effectiveness of online learning as teachers' educational experience and the contextual factors related to access to internet and technology (Carrillo \& Flores, 2020). Socioeconomic condition as the contextual limitations can prevent students from attending classes given the level of access to the technology or study conditions (Tran et al., 2020).

Despite these observed complexities, the correlations between beliefs and practice variables show that teachers who appreciate fewer difficulties and feel more capable of using technology in teaching processes perceive that their students are more active to participate in online classes. This is consistent with the results reported in other studies referring to beliefs and instructional practices, where teachers state that the focus of the new remote teaching paradigm is the student, so all strategies must go in the direction of recognizing the knowledge that the student learns in context (Carrillo \& Flores, 2020; Rasmitadila et al., 2020). Along these lines, Santi and his colleagues (2020) argue that teachers must turn students into reliable and responsible people, as active partners in the process of their own training, taking advantage of the levels of 
digital literacy they have to reinforce their levels of resilience and autonomy in learning (Tran et al., 2020).

The results of the present study and the literature show that the belief and practice system associated with remote teaching processes is strongly influenced by external factors to teachers. This is based on the fact that municipal school teachers present the most negative beliefs and private school teachers the most positive ones. This pattern is consistent across all variables. These results indicate that the beliefs and practices of teachers in relation to technology are strongly mediated by the context and socioeconomic level of the school. When comparing this evidence with the factors mentioned by Carrillo and Flores (2020), we can conclude that the cognitive and educational experience components are not relevant to seal the difference between the beliefs and instructional practices of teachers who belong to different types of establishments. Though, no significant differences have been observed between men and women, nor by years of experience. This part of the results is in line with what was observed in the 2010s (Corry \& Stella, 2018), but not a decade ago, where research suggested that older teachers had lower levels of self-efficacy in the classroom in the use of the Web (Lee \& Tsai, 2000). It means, teachers, regardless of their age, gender, and the levels of anxiety or stress presented, vary their practices due to some external conditions. The latter can be explained by the globalization and democratization of technology in today's society, which is observed when comparing the studies of Bakar et al. (2020), and Lee and Tsai (2000), who report an advance in knowledge and the use of technology, progress that is not observed with the same impetus in the integration of these in the teaching and learning processes of mathematics. Teachers believe that the instructional strategy requires a change and that all stakeholders, including governments, schools, social organizations, school communities and parents, should determine and formulate objectives for learning that are in line with a national studies plan (Rasmitadila et al., 2020).

The results confirm that the belief systems and associated practices of teachers are highly influenced by context situations. The pandemic has shown that conditions of uncertainty and lack of resources throughout the educational community affect the cognitive and affective domains of a teacher's professional competence, as well as the pedagogical decisions of key actors related to teaching and learning processes, with the family and the home being an actor and spaces that have taken precedence. According to the findings, teachers' gender does not play an important role in teachers' self-efficacy in using or teaching with technology. This information can change the stereotype bias that men have more confidence in using technology than women. Moreover, when we decompose the information based on the type of schools, we observe that the differences between teachers' schools bring significant differences on teachers' beliefs and practices that should be considered by policymakers in order to reduce the segregation and inequality in education. Such information suggests that improving teachers' abilities in public and subsidized systems is an important factor for improving teachers' practices during the pandemic. However, the models of knowledge and professional competence must consider that the framework of cognitive and affective dispositions are influenced by the situated scenario that a teacher has to make decisions and perform professionally, perpetuating a cycle of modification of beliefs due to the context observed in the instructional practices.

\section{Practical Implications for Teaching and Learning}

These research results provide evidence for decisionmaking in public policies to overcome the complex situation experienced by remote education teachers. Recognition of teachers' beliefs, practices, the interrelation between types of schools, the characteristics of teachers, and their influence on teachers' practices, may allow PD program designers, organizers, and practitioners, at least in the Chilean context, to foresee more opportunities leading to adequate professional education improvement in the future. Although teachers must be supported with technological resources and training models in the design and didactic management for the integration of technologies in remote education, they must also be provided with resources to address stress and anxiety situations that could affect student levels of self-efficacy. The families of the teachers' students must be supported with the same force, since the lack of resources and quality of the internet, such as the provision of adequate spaces, directly intervenes in the ability to learn and attend remote education. If the purposes of training are considered, families and homes have been a pillar of remote education, but they do not have the capacity and training to complement what is provided by teachers, therefore professional development programs are necessary for them to be incorporated into the didactic models of remote education.

\section{Limitation of the Study and Future Research}

Due to the pandemic, we utilized an online purposive sampling method by using the available resources, which brought a nonprobability sample in this study. It can influence the results since the profile of the sample may be a biased representation of Chilean in-service mathematics teachers in general. Therefore, in order to ensure the generalizability of the results, future research may go through getting a permission from the Chilean ministry of education to access their data set of all Chilean teachers, which allows access to a larger and randomized sample of mathematics teachers. As we used self-reported practices, it is important to identify if the responses are systematically biased toward 
respondents' perceptions of what is socially acceptable. In this case, we suggest including a desirability scale to control if social desirability represents contamination of the data in future studies. Regarding the variables of the study, we believe that they are more critical variables to study in this belief/practice structure. We recommend a purposive interview with some expert teachers to find out if they believe that their perceptions and practices can be influenced by other variables. It is also recommended that future studies consider the changes or evolution in teachers' practices in the second year of this remote education, since the schools are still closed in many countries. Finally, we suggest further research into how the variables may function in other cultures. Considering the validity of the instrument in different contexts, it would be valuable to find out the effect of different educational cultures and systems on how teachers' perceptions and practices were affected by teaching mathematics during the pandemic.

Author contributions: All authors have sufficiently contributed to the study, and agreed with the results and conclusions.

Funding: Authors gratefully acknowledge funding from PIACONICYT Basal Funds for Centers of Excellence Project FB0003. VG thanks ANID-FONDECYT No.11180798. EC also thanks ANID-FONDECYT Postdoctoral No. 3201094.

Declaration of interest: No conflict of interest is declared by authors.

\section{REFERENCES}

Alemany-Arrebola, I., Rojas-Ruiz, G., Granda-Vera, J., \& Mingorance-Estrada, Á. C. (2020). Influence of COVID-19 on the perception of academic selfefficacy, state anxiety, and trait anxiety in college students. Frontiers in Psychology, 11, 570017. https:/ / doi.org/10.3389/fpsyg.2020.570017

Ally, M. (2008). Foundations of educational theory for online learning. In T. Anderson (Ed.). The theory and practice of online learning (pp. 15-44). Athabasca University Press. http:/ / www.aupress.ca/books/ 120146/ebook/01_Anderson_2008-Theory_and_ Practice_of_Online_Learning.pdf

Almanthari, A., Maulina, S., \& Bruce, S. (2020). Secondary school mathematics teachers' views on e-learning implementation barriers during the COVID-19 pandemic: The case of Indonesia. Eurasia Journal of Mathematics, Science and Technology Education, 16(7), em1860. https:/ / doi.org/10.29333/ ejmste/8240

Arpaci, I., \& Basol, G. (2020). The impact of preservice teachers' cognitive and technological perceptions on their continuous intention to use flipped classroom. Education and Information Technologies, 25, 3503-3514. https://doi.org/10.1007/s10639020-10104-8

Azevedo, J. P., Hasan, A., Goldemberg, D., Iqbal, S. A., \& Geven, K. (2020). Simulating the potential impacts of Covid-19 school closures on schooling and learning outcomes: A set of global estimates. https:/ / doi.org/10.1596/1813-9450-9284

Bakar, N. S. A., Maat, S. M., \& Rosli, R. (2020). Mathematics teacher's self-efficacy of technology integration and technological pedagogical content knowledge. Journal on Mathematics Education, 11(2), 259-276.

http:/ / doi.org/10.22342/jme.11.2.10818.259-276

Bandura, A. (1997). Self-efficacy: The exercise of control. W H Freeman/Times Books/ Henry Holt \& Co.

Bravo, D., \& Castillo, E. (2020). Estudio Longitudinal Empleo-Covid19: Datos de empleo en tiempo real [Longitudinal Study Employment-Covid19: Employment data in real time] [Conference presentation]. Seminario y Conferencia de Prensa Centro UC Encuestas y Estudios Longitudinales, Chile. http://www.encuestas.uc.cl/img/nuevas/ Presentacion-Seminario-10jun.pdf

Carrillo, C., \& Flores, M. A. (2020). COVID-19 and teacher education: a literature review of online teaching and learning practices. European Journal of Teacher Education, 43(4), 466-487. https://doi.org/ 10.1080/02619768.2020.1821184

Castro, W. F., Pino-Fan, L. R., Lugo-Armenta, J. G., Toro, J. A., \& Retamal, S. (2020). A mathematics education research agenda in Latin America motivated by coronavirus pandemic. EURASIA Journal of Mathematics, Science and Technology Education, 16(12), em1919. https:/ / doi.org/10.29333/ejmste/ 9277

Centro de Investigación Avanzada en Educación (CIAE). Centro de Investigación para la Educación Inclusiva (CIEI) y EDUGLOBAL: Red de Servicios para la Educación (EDUGLOBAL). (2020). COVID19 Nuevos Contextos, Nuevas Demandas y Experiencia Docente en Chile. Santiago, Chile. http:/ / www.ciae.uchile.cl/index.php?page=view _noticias\&langSite $=$ es\&id $=2072$

Corry, M., \& Stella, J. (2018). Teacher self-efficacy in online education: a review of the literature. Research in Learning Technology, 26, 1-12. https: / / doi.org/10.25304/rlt.v26.2047

De Ponte, J. P., Oliveira, H., \& Varandas, J. M. (2002). Development of preservice mathematics teachers' professional knowledge and identity in working with information and communication technology. Journal of Mathematics Teacher Education, 5(2), 93115. https:/ / doi.org/10.1023/ A:1015892804607

Giaconi, V., Perdomo, J., Cerda, G., \& Saadati, F. (2018). Prácticas docentes, autoeficacia y valor en relación con la resolución de problemas de matemáticas: diseño y validación de un cuestionario [Teaching practices, self-efficacy and value in relation to solving mathematics problems: design and validation of a questionnaire]. Enseñanza de las 
ciencias, 36(3), 99-120. https://doi.org/10.5565 /rev/ensciencias.2351

Gillis, A., \& Krull, L. M. (2020). COVID-19 remote learning transition in Spring 2020: Class structures, student perceptions, and inequality in college courses. Teaching Sociology, 48(4), 283-299. https:// doi.org/10.1177/0092055X20954263

Guskey, T. R. (2002). Professional development and teacher change. Teachers and Teaching, 8(3), 381-391. https:/ / doi.org/10.1080/135406002100000512

Horvitz, B. S., Beach, A. L., Anderson, M. L., \& Xia, J. (2015). Examination of faculty self-efficacy related to online teaching. Innovative Higher Education, 40(4), 305-316. https://doi.org/10.1007/s10755014-9316-1

Huffman, A. H., Whetten, J., \& Huffman, W. H. (2013). Using technology in higher education: The influence of gender roles on technology selfefficacy. Computers in Human Behavior, 29(4), 17791786. https:/ / doi.org/10.1016/j.chb.2013.02.012

Juggernath, A., \& Govender, N. (2020). Natural Sciences Teachers' Beliefs as Barriers for Integrating ICTs in a Technology-rich Context. African Journal of Research in Mathematics, Science and Technology Education, 24(1), 105-115. https:/ / doi.org/10.1080/ 18117295.2020.1736854

Karatas, I. (2014). Changing pre-service mathematics teachers' beliefs about using computers for teaching and learning mathematics: the effect of three different models. European Journal of Teacher Education, 37(3), 390-405. https://doi.org/10.1080/ 02619768.2013 .870993

Keebler, D. W., \& Huffman, J. (2020). Effective eLearning and transformative pedagogical strategies: STEM programs. International Journal of Online Pedagogy and Course Design (IJOPCD), 10(2), 61-70. https:/ / doi.org/10.4018/IJOPCD.2020040105

Kersaint, G. (2007). Toward technology integration in mathematics education: A technology-integration course planning assignment. Contemporary Issues in Technology and Teacher Education, 7(4), 256-278.

Kline, R. B. (2016). Principles and practice of structural equation modeling. Guilford publications.

Kreber, C., \& Cranton, P. A. (2000). Exploring the scholarship of teaching. The Journal of Higher Education, 71(4), 476-496. https:/ / doi.org/10.2307/ 2649149

Lee, M. H., \& Tsai, C. C. (2010). Exploring teachers perceived self efficacy and technological pedagogical content knowledge with respect to educational use of the World Wide Web. Instructional Science, 38(1), 1-21. https://doi.org/ $10.1007 /$ s11251-008-9075-4
Levin, T., \& Wadmany, R. (2006). Teachers' beliefs and practices in technology-based classrooms: A developmental view. Journal of research on technology in education, 39(2), 157-181. https:/ / doi.org/10.1080/15391523.2006.10782478

Marshall, D. T., Shannon, D. M., \& Love, S. M. (2020). How teachers experienced the COVID-19 transition to remote instruction. Phi Delta Kappan, 102(3), 4650. https:/ / doi.org/10.1177/0031721720970702

McDonald, T., \& Siegall, M. (1992). The effects of technological self-efficacy and job focus on job performance, attitudes, and withdrawal behaviors. The Journal of Psychology, 126(5), 465-475. https:/ / doi.org/10.1080/00223980.1992.10543380

Ministry of Education Republic of Chile [MINEDUC] (2021). Registro de Cargos Docentes 2020 [Teacher positions registered in 2020]. Ministerio de Educación. http://datos.mineduc.cl/dashboards/ 20031/descarga-bases-de-datos-de-cargosdocentes /

Mumtaz, S. (2000). Factors affecting teachers' use of information and communications technology: a review of the literature. Journal of information technology for teacher education, 9(3), 319-342. https:// doi.org/10.1080/14759390000200096

OECD. (2020). Education at a Glance 2020: OECD Indicators. OECD Publishing.

Prawat, R. S. (1992). Teacher's beliefs about teaching and learning: A constructivist perspective. American Journal of Education, 100(3), 354-394. https:// doi.org/10.1086/444021

Rasmitadila, R., Aliyyah, R. R., Rachmadtullah, R., Samsudin, A., Syaodih, E., Nurtanto, M., \& Tambunan, A. R. S. (2020). The perceptions of primary school teachers of online learning during the COVID-19 pandemic period: A case study in Indonesia. Journal of Ethnic and Cultural Studies, 7(2), 90-109. https:// doi.org/10.29333/ ejecs/388

Revelle, W. (2020). Psych: Procedures for personality and psychological research. Northwestern University, Evanston, Illinois, USA. https://CRAN.Rproject.org $/$ package $=$ psych

Rios, J., \& Wells, C. (2014). Validity evidence based on internal structure. Psicothema, 26(1), 108-116. https:// doi.org/10.7334/psicothema2013.260

Rosseel, Y. (2012). Lavaan: An R package for structural equation modeling. Journal of Statistical Software, 48(2), 1-36. https:// doi.org/10.18637/jss.v048.i02

Saadati, F., Cerda, G., Giaconi, V., Reyes, C., \& Felmer, P. (2019). Modeling Chilean mathematics teachers' instructional beliefs on problem solving practices. International Journal of Science and Mathematics Education, 17(5), 1009-1029. https://doi.org/ 10.1007/s10763-018-9897-8 
Santi, E. A., Gorghiu, G., \& Pribeanu, C. (2020). Teachers' perceived self-efficacy for mobile teaching and learning. Revista Romaneasca pentru Educatie Multidimensionala, 12(1Sup2), 157-166. https://doi.org/10.18662/rrem/12.1sup2/259

Schultz, K. S., Whitney, D. J., \& Zickar (2014). Measurement theory in action: Case studies and exercises (2nd Ed.). Routledge.

Sepulveda-Escobar, P., \& Morrison, A. (2020). Online teaching placement during the COVID-19 pandemic in Chile: challenges and opportunities, European Journal of Teacher Education, 43(4), 587-607. https:/ / doi.org/10.1080/02619768.2020.1820981

Slough, S. W., \& Chamblee, G. E. (2000). Implementing technology in secondary science and mathematics classrooms: A perspective on change. In Society for Information Technology $\mathcal{E}$ Teacher Education International Conference (pp. 1021-1026). Association for the Advancement of Computing in Education (AACE).

Stipek, D. J., Givvin, K. B., Salmon, J. M., \& MacGyvers, V. L. (2001). Teachers' beliefs and practices related to mathematics instruction. Teaching and Teacher Education, 17(2), 213-226. https:/ / doi.org/10.1016/ S0742-051X(00)00052-4

Teo, T. (2009). Examining the relationship between student teachers' self-efficacy beliefs and their intended uses of technology for teaching: A structural equation modeling approach. Turkish
Online Journal of Educational Technology, 8(4), 7-16. https://www.tojet.net/articles/v8i4/841.pdf

The World Bank (2021, February 22). Two-thirds of poorer countries are cutting education budgets due to COVID19. https://www.worldbank.org/en/news/pressrelease/2021/02/22/two-thirds-of-poorercountries-are-cutting-education-budgets-due-tocovid-19

Thompson, A. G. (1992). Teachers' beliefs and conceptions: A synthesis of the research. In D. A. Grouws (Ed.), Handbook of research on mathematics teaching and learning (pp. 127-146). Macmillan.

Tran, T., Hoang, A. D., Nguyen, Y. C., Nguyen, L. C., Ta, N. T., Pham, Q. H., Pham, C. X., Le, Q. A., Ding, V. H., \& Nguyen, T. T. (2020). Toward sustainable learning during school suspension: Socioeconomic, occupational aspirations, and learning behavior of Vietnamese students during COVID-19. Sustainability, 12(10), 4195. https:/ / doi.org/10.3390 / su12104195

UNESCO (2020). COVID-19 educational disruption and response, UNESCO. https://en.unesco.org/ covid19/educationresponse

Wachira, P., \& Keengwe, J. (2011). Technology integration barriers: Urban school mathematics teachers' perspectives. Journal of Science Education and Technology, 20(1), 17-25. https://doi.org/ 10.1007/s10956-010-9230-y 


\section{APPENDIX}

\begin{tabular}{|c|c|c|}
\hline Item & Original version in Spanish & English translation \\
\hline$\overline{\text { STP } 1}$ & $\begin{array}{l}\text { Puedo utilizar la tecnología para comunicarme con } \\
\text { familiares o amigos }\end{array}$ & $\begin{array}{l}\text { I can use technology to communicate with relatives and } \\
\text { friends }\end{array}$ \\
\hline STP 2 & $\begin{array}{l}\text { Cuando necesito saber algo o tengo un problema puedo } \\
\text { buscar soluciones o respuestas en internet de manera } \\
\text { exitosa }\end{array}$ & $\begin{array}{l}\text { When I need information or have a problem, I can find } \\
\text { proper solutions and answers on the internet }\end{array}$ \\
\hline STP 3 & $\begin{array}{l}\text { Puedo crear contenidos digitales (página web, blogs, } \\
\text { vídeo YouTube, etc.) }\end{array}$ & $\begin{array}{l}\text { ate digital content (website, blogs, YouTube } \\
\text { c.) }\end{array}$ \\
\hline STP 4 & $\begin{array}{l}\text { Puedo usar la tecnología para hacer clases y/o actividac } \\
\text { en línea }\end{array}$ & $\begin{array}{l}\text { I can use technology to implement online classes or } \\
\text { activities }\end{array}$ \\
\hline STP 5 & $\begin{array}{l}\text { Puedo participar y seguir información en distintas redes } \\
\text { sociales }\end{array}$ & $\begin{array}{l}\text { I can participate and follow up content in different online } \\
\text { social networks/platforms }\end{array}$ \\
\hline STP 6 & $\begin{array}{l}\text { Puedo encontrar en internet recursos y materiales para } \\
\text { mis estudiantes mis estudiantes }\end{array}$ & $\begin{array}{l}\text { I can locate resources and materials online to share with } \\
\text { students }\end{array}$ \\
\hline STT 1 & $\begin{array}{l}\text { Puedo planificar y ejecutar con éxito actividades en línea } \\
\text { para mis estudiantes }\end{array}$ & $\begin{array}{l}\text { I can successfully plan and deliver online activities to my } \\
\text { students }\end{array}$ \\
\hline STT 2 & $\begin{array}{l}\text { Puedo evaluar el avance de mis estudiantes durante mis } \\
\text { clases y/o actividades en línea }\end{array}$ & $\begin{array}{l}\text { I can assess my students progress during my online } \\
\text { instruction }\end{array}$ \\
\hline STT 3 & $\begin{array}{l}\text { Puedo motivar a mis estudiantes a participar de las clases } \\
\text { y/o actividades en línea }\end{array}$ & I can motivate students to participate in online learni \\
\hline STT 4 & $\begin{array}{l}\text { Puedo guiar y establecer diálogo con mis estudiantes para } \\
\text { mediar sus aprendizajes en clases y/o actividades en línea }\end{array}$ & $\mathrm{n}$ \\
\hline STT 5 & $\begin{array}{l}\text { Puedo enseñar en línea los misn } \\
\text { gestiono en mis clases y/o activi }\end{array}$ & $\begin{array}{l}\text { I can teach online the same content that I deliver in my } \\
\text { face-to-face classes }\end{array}$ \\
\hline BPT 1 & Enseñar en línea me resulta difícil & I found online teaching hard \\
\hline BPT 2 & duce la motivac & ching de \\
\hline BPT 3 & $\begin{array}{l}\text { Enseñar en línea hace más difícil monitorear el progreso } \\
\text { de los estudiantes que en una clase presencial }\end{array}$ & $\begin{array}{l}\text { Online teaching makes it more difficult to monitor stude } \\
\text { progress as compared to face-to-face instruction }\end{array}$ \\
\hline BPT 4 & $\begin{array}{l}\text { Enseñar en línea me permite dar feedback personalizado a } \\
\text { cada estudiante }\end{array}$ & $\begin{array}{l}\text { Online teaching allows me to provide individualized } \\
\text { feedback to my student }\end{array}$ \\
\hline BPT 5 & $\begin{array}{l}\text { Enseñar en línea da la posibilidad de hacer pruebas u otro } \\
\text { tipo de evaluación para calificar a mis estudiantes }\end{array}$ & $\begin{array}{l}\text { Online teaching allows me for implementing different } \\
\text { assessment strategies to monitor student progress }\end{array}$ \\
\hline BPT 6 & $\begin{array}{l}\text { Enseñar en línea me resulta más interesante que una clase } \\
\text { presencial }\end{array}$ & $\begin{array}{l}\text { Online teaching is more interesting to me than a face-to- } \\
\text { face teaching }\end{array}$ \\
\hline BPT 7 & $\begin{array}{l}\text { Enseñar en línea me permite controlar los tiempos de una } \\
\text { clase y/o actividad }\end{array}$ & $\begin{array}{l}\text { Online teaching allows me to control the pace and } \\
\text { activities of a lesson }\end{array}$ \\
\hline BPT 8 & $\begin{array}{l}\text { Enseñar en línea me permite ampliar y diversificar los } \\
\text { recursos de aprendizaje }\end{array}$ & $\begin{array}{l}\text { Online teaching allows me to broaden and diversify } \\
\text { learning resources }\end{array}$ \\
\hline BBT 1 & $\begin{array}{l}\text { Me resulta difícil organizar y planificar mis clases y/o } \\
\text { actividades en línea }\end{array}$ & $\begin{array}{l}\text { It is difficult for me to plan my online lessons and } \\
\text { activities }\end{array}$ \\
\hline BBT 2 & $\begin{array}{l}\text { Cuando comienzo a enseñar en línea, los retrasos e } \\
\text { interrupciones de mis estudiantes para unirse a la cl }\end{array}$ & $\begin{array}{l}\text { Students arriving late to my online class and their } \\
\text { interruptions cause a lot of problems }\end{array}$ \\
\hline
\end{tabular}
me causan problemas

\begin{tabular}{|c|c|c|}
\hline BBT 3 & $\begin{array}{l}\text { Afecta mi enseñanza cuando tengo problemas técnicos o } \\
\text { de conexión a internet }\end{array}$ & $\begin{array}{l}\text { Dealing with connecting and technological issues affects } \\
\text { my instructions }\end{array}$ \\
\hline BBT 5 & $\begin{array}{l}\text { Las clases en línea me generan menor distracción que las } \\
\text { clases presenciales }\end{array}$ & $\begin{array}{l}\text { I feel online instruction causes more distraction than face- } \\
\text { to-face classes }\end{array}$ \\
\hline BBT 6 & $\begin{array}{l}\text { Preparar las clases en línea requiere más tiempo que } \\
\text { preparar mis clases presenciales }\end{array}$ & $\begin{array}{l}\text { Planning my online instructional activities takes more } \\
\text { time than my face-to-face instruction }\end{array}$ \\
\hline \multirow[t]{2}{*}{ BBT 7} & $\begin{array}{l}\text { para adaptar mis actividades } \\
\text { prácticas en línea }\end{array}$ & $\begin{array}{l}\text { I have difficulties implementing face-to-face activities in } \\
\text { an online learning setting }\end{array}$ \\
\hline & $\begin{array}{l}\text { Tengo dificultades para responder las preguntas que los } \\
\text { estudiantes hacen }\end{array}$ & $\begin{array}{l}\text { I have difficulty responding to my students' questions in } \\
\text { online/remote teaching }\end{array}$ \\
\hline PR_T 1 & $\begin{array}{l}\text { Propongo actividades para que mis estudiantes puedan } \\
\text { discutir y compartir sus opiniones }\end{array}$ & $\begin{array}{l}\text { that allow my students to } \\
\text { ions and share opinions }\end{array}$ \\
\hline PR_T 2 & $\begin{array}{l}\text { Mis clases y/o actividades en línea se enfocan en abarcar } \\
\text { los contenidos mínimos obligatorios }\end{array}$ & $\begin{array}{l}\text { My online classes are focused on covering the minimum } \\
\text { content requirements }\end{array}$ \\
\hline PR_T 3 & $\begin{array}{l}\text { Yo envío material, texto, PowerPoint, etc., a mis } \\
\text { estudiantes para ayudarles a entender }\end{array}$ & $\begin{array}{l}\text { I help my students understand, I provide them material, } \\
\text { text, PowerPoint, etc. }\end{array}$ \\
\hline PR_T 4 & $\begin{array}{l}\text { Propongo problemas a modo de explicación y luego } \\
\text { gestiono problemas similares a mis estudiantes }\end{array}$ & $\begin{array}{l}\text { I explain problems/activities and then assign my students } \\
\text { similar problems to solve }\end{array}$ \\
\hline
\end{tabular}




\begin{tabular}{|c|c|c|}
\hline Item & Original version in Spanish & English translation \\
\hline PR_T 5 & $\begin{array}{l}\text { Hago preguntas a mis estudiantes para asegurarme de } \\
\text { que todos/as están comprendiendo la clase y/o } \\
\text { actividades }\end{array}$ & $\begin{array}{l}\text { I ask my students questions to make sure they understan } \\
\text { during class and activities }\end{array}$ \\
\hline PR_T 6 & $\begin{array}{l}\text { Incentivo a mis estudiantes a enviar preguntas o dudas } \\
\text { sobre la clase en línea y/o actividades }\end{array}$ & have about our online activities \\
\hline PR_T 7 & $\begin{array}{l}\text { Actúo como mediador del proceso de enseñanza- } \\
\text { aprendizaje de mis estudiantes en clases y/o actividades } \\
\text { en línea }\end{array}$ & $\begin{array}{l}\text { In my online instruction I act as a mediator in the } \\
\text { teaching-learning process }\end{array}$ \\
\hline PR_T 8 & $\begin{array}{l}\text { Propongo resolver problemas en mis clases y/o } \\
\text { actividades en línea }\end{array}$ & roblems to solve in my online classes and \\
\hline PR_T 9 & $\begin{array}{l}\text { Participo en algún grupo de WhatsApp o un foro de } \\
\text { discusión para recibir y responder preguntas de mis } \\
\text { estudiantes }\end{array}$ & $\begin{array}{l}\text { I participate in meetings and online discussion forums } \\
\text { (e.g., WhatsApp groups) with my students to receive and } \\
\text { respond to their questions }\end{array}$ \\
\hline PR_T 10 & $\begin{array}{l}\text { ases en línea mantengo contacto con mis } \\
\text { para monitorearles }\end{array}$ & ses I maintain contact with my \\
\hline PR_S 1 & nis clases y/o revisan las & s and/or study \\
\hline PR_S 2 & en preguntas durante mis clases y/o & $\begin{array}{l}\text { My s } \\
\text { activ }\end{array}$ \\
\hline PR_S 3 & $\begin{array}{l}\text { ticipan respondiendo preguntas } \\
\text { o actividades en línea }\end{array}$ & $\begin{array}{l}\text { During online instruction and activitie } \\
\text { participate by responding to teacher } / \mathrm{s} \\
\text { questions }\end{array}$ \\
\hline PR_S 4 & $\begin{array}{l}\text { Mis estudiantes utilizan los recursos tecnológicos (ej: } \\
\text { Wikipedia, YouTube, google, etc.) a su disposición para } \\
\text { reforzar y mejorar su aprendizaje }\end{array}$ & $\begin{array}{l}\text { My students use all the technological tools (e.g., } \\
\text { Wikipedia, YouTube, Google, etc.) they have available to } \\
\text { support and improve their learning }\end{array}$ \\
\hline PR_S 5 & $\begin{array}{l}\text { Mis estudiantes utilizan redes sociales (ej: Facebook, } \\
\text { Instagram, etc.) a su disposición para reforzar y mejorar } \\
\text { su aprendizaje }\end{array}$ & $\begin{array}{l}\text { My students use social platforms (e,g., Facebook, } \\
\text { Instagram, etc.) they have available to support and } \\
\text { improve their learning }\end{array}$ \\
\hline PR_S6 & Mis estudiantes siguen las clases y/o actividades en línea & My students follow my online instruction \\
\hline PR_S 7 & Mis estudiantes resuelven problemas de matemáticas & My students solve mathemati \\
\hline PR_S 8 & $\begin{array}{l}\text { Mis estudiantes publican algunos problemas matemáticos } \\
\text { en espacios virtuales (ej: WhatsApp, Foro, etc.) }\end{array}$ & $\begin{array}{l}\text { My students use social networks to post their } \\
\text { mathematics problems (e.g., WhatsApp, discussion } \\
\text { forums, etc.) }\end{array}$ \\
\hline S9 & $\begin{array}{l}\text { Mis estudiantes comparten entre ellos pr } \\
\text { que se trabaja en espacios virtuales (grup } \\
\text { Foro, etc.) }\end{array}$ & $\begin{array}{l}\text { My students share among themselves questions about } \\
\text { what they are working on in virtual platforms (e.g., } \\
\text { WhatsApp, discussion forums, etc.) }\end{array}$ \\
\hline
\end{tabular}

\section{http://www.ejmste.com}

